\title{
Needs Analysis of English for Specific Purposes in Vocational High School Level
}

\author{
Fresa Permata Sari*, Yanty Wirza
}

\author{
English Education Department, Universitas Pendidikan Indonesia \\ *Corresponding author. Email: permatafresa@gmail.com
}

\begin{abstract}
This paper aims to investigate the needs of the Office Authorization and Governance students in learning English in terms of target needs, learning needs, and present situation. The study employed a case study method where the data were gained from the interview to one English teacher of one of the vocational schools in Bandung, the questionnaire to thirty students in one class of $10^{\text {th }}$ grade of Office Authorization and Governance (OTKP), and also documents including syllabus, lesson plans, and the students' assignments. The results of the research show that in terms of the most needed English skills, the students need speaking and writing skills in specific purposes for the future work in the field of Office Authorization and Governance (OTKP) as secretary, manager, receptionist, and so on. However, English taught in the learning activities in the vocational school was General English (GE), which was less appropriate and fitting for vocational students to meet the target needs. The Office Authorization and Governance (OTKP) students needed EVP (English for Vocational Purposes) particularly on the improvement of skills and knowledge needed by target needs, such as speaking to native or non-native speakers in business context and writing reports. Furthermore, the Office Authorization and Governance (OTKP) major should be provided with appropriate lessons and skills to prepare them for the future job markets.
\end{abstract}

Keywords: English for Specific Purposes (ESP), English for Vocational Purposes (EVP), Needs Analysis, Office Authorization and Governance (OTKP)

\section{INTRODUCTION}

Vocational high school is one of the secondary levels of education in Indonesia. Vocational high school is chosen by people for entering the industries for the first time and focusing on the skills that students need in the work field. According to Republic of Indonesia Ministry of Education and Culture's regulations number 34 of 2018 regarding to the National Standard of Vocational High School (SMK)/Vocational Madrasah Aliyah (MAK), vocational school (SMK/MAK) is one of the high schools which produce graduates who can work in the industries. The Republic of Indonesia Ministry of Education and Culture mentioned that industries need employees who have good skills related to the work field. Therefore, the SMK/MAK graduates should have the specific skills, especially in English to compete in workplace.

Nowadays, vocational high schools in Indonesia have been working on improving the quality of the teaching and learning process. Although some improvements have been made, vocational high schools in Indonesia are still lagging behind the quality of vocational students in other countries. Based on Global
Business Guide Indonesia (2016), one of the reasons for the problems is due to mismatch between the skills and practical training. The skills of Indonesian Vocational High School related to English comprehension need improvements, whereas the skills are not certainly matched to the demands of the industries.

In line with this, the vocational students should learn English for Specific Purposes (ESP). According to Hutchinston and Waters (1987), English for Specific Purposes (ESP) is needed by people who worked in the specific fields such as medical, military, business, and other fields. However, there are many students at vocational high schools who do not know ESP in teaching and learning process. This happens due to the lack of knowledge regarding needs analysis to students in vocational school, including in field of Office Authorization and Governance (Mahbub, 2018). The needs of the industries of ESP are certainly affecting the teaching and learning process for the students in vocational schools (Long, 2005). In Office Authorization and Governance, most of the students have not met the needs for their future work. 
Needs analysis is used to find out the students' needs. It has already been known around the world and it has already been implemented in some schools, such as United States of America (Long, 2005), Turkey (Akyel \& Ozek, 2010), and the other countries (Mahbub, 2018). The demands of English in education and work field have been increasing in the recent years (Long, 2005). The needs of the industries of ESP certainly affect the teaching and learning process for the students in vocational schools (Long, 2005). In Office Authorization and Governance, the needs of English skills are four traditional skills (listening, speaking, reading and writing), grammar and vocabulary. The students are still lack of English skills, especially in English for Specific Purposes (ESP). Therefore, the students' needs of English skills should be improved and it is related to the teaching activities and materials. In line with this, the needs of the vocational students found by many researchers, in terms of the syllabus and the teaching and learning process. Rarely did researchers analyze the needs in terms of the relation between the syllabus, teaching and learning materials to the skills needed in the industries, especially in Office Authorization and Governance. Most of the researchers have focused only on the textbook, the syllabus and teaching and learning activity separately (Poedjiastutie \& Oliver, 2017)

Based on the problems, this research was constructed to find out the students' needs according to the relation of the syllabus to teaching and learning materials and the skills for the industries in Office Authorization and Governance.

\section{LITERATURE REVIEW}

\subsection{Indonesian English for Specific Purposes (ESP)}

In teaching and learning English, especially for vocational school, English for Specific Purposes (ESP) has already been known by the teachers and the learners. ESP used by the teacher to help students to achieve their goals in specific fields, including the skills needed by the students (Sarmento, Viana, \& Bocorny, 2018).

ESP has three main branches: English for Science and Technology (EST), English for Business and Economics (EBE), and English for Social Sciences (ESS) (Hutchinston \& Waters, 1987). Office Authorization and Governance is included in EBE, which is used by accountants, lawyers, finance specialists, etc. (Rao, 2017). Those three main branches are also divided into English for Academic Purposes (EAP) and English for Occupational Purposes (EOP). EAP is a type of ESP which is relevant with the students who are planning to continue their study in university (Kostka \& Olmsteed-Wang, 2014). EAP is commonly used in Senior High School. On the other hand, EOP is focusing on students' skills for the work field. In line with this, EOP is related to English in the workplace (Marra, 2013).

ESP in Indonesia has not been implemented properly, especially in EOP. However, EAP turns into general type of English used in most schools and universities in Indonesia (Aniroh, 2017). The vocational students need ESP to improve their specific knowledge and skills. The demands of the industries need vocational graduates who have specific knowledge and skills based on the job desks. Despite the facts, the English teacher at one vocational school in Bandung is still not implementing the ESP by reason of the lack of knowledge of ESP teaching. So, the students are not getting ESP yet both in teaching and learning activity. In addition, Office Authorization and Governance need ESP as secretary, manager, receptionist, and so on.

\subsection{Office Authorization and Governance (known as "OTKP" in Indonesia)}

Office Authorization and Governance or known as Office Administration plans the production of the factory, controlling the production, managing the organization in factory, connecting the works of the factory, working on the documents, and so on (Eyre, 1989). In Indonesia, it is called Otorisasi dan Tata Kelola Perkantoran (OTKP) or Administrasi Perkantoran (AP). There are no differences between Office Authorization and Governance and Office Administration. It only changed its name for the major in vocational high school.

Most of the students who took Office Authorization and Governance field want to work in office as secretary or manager. Nowadays, a secretary or manager should have good English skills related to the business field. The industries around the world need workers from Office Authorization and Governance areas who have good ability to handle the tasks, have good vision and coordination to the other officers (Zhang, 2016), and have skills in mastering English (listening, speaking, reading, and writing).

The big demands of the industries make the students who learn English for Office Authorization and Governance have difficulties to comprehend the skills, such as having conversation, reading e-mail, talking of companies, completing letters, etc. The teachers are also having a problem in dividing the theory and practice in teaching English for the students (Kareva, 2013). The problems happened in OTKP needs ESP in terms of English for Vocational Purposes (EVP) to help the students improve their knowledge and skills in specific.

\subsection{English for Vocational Purposes (EVP)}

English for Vocational Purposes is a part of ESP and EOP (Hutchinston \& Waters, 1987). EVP focuses on specific fields, trades, or occupation (Lesiak-Bielawska, 2012). EVP is needed for designing ESP materials in vocational school (Widodo, 2016). Widodo (2016) also 
mentioned that EVP is needed for vocational students in terms of improving knowledge and skills for the work fields.

EVP has not been implemented properly in Indonesia, both in vocational school and university. However, the vocational school and university are still implementing General English (GE) as its standard. Teaching and learning English in Indonesia is challenging by cause of the social environment is not using English as their first or second language. This is also affecting EVP in vocational school or university. In addition, the implementation of EVP is related to needs analysis of the students to gain the information of what students need in learning English for OTKP.

\subsection{Needs Analysis}

Hutchinston and Waters (1987) divided needs analysis into two categories: Target Needs and Learning Needs. Target needs is the needs of the students in target situation. Target needs are divided into three components: necessities, lacks, and wants. Necessities is the type of target needs based on the demands of the target situation. The necessities cannot be identified without lacks. Lacks is the type of target needs which analyse lack of students' learning process. Connected with necessities and lacks, the students also have their wants in learning English. Wants is the type of target needs which are the students' needs in comprehending the skills. While necessities and lacks are analyzing students' needs based on the majors and the skills needed in the work fields, wants are analyzing students' needs based on the skills that students want to comprehend. In Office Authorization and Governance, the students are still in progress to improve the skills in writing and speaking regarding to their needs (Feak, 2013). However, the students can comprehend the skills in listening and reading, if they have competencies in comprehending those skills.

Furthermore, there is Present Situation Analysis (PSA) which is used to find out the learners' strengths and weaknesses in learning English (Li, 2014). According to Bloor, Hutchinston and Waters, and Richard (cited in Li, 2014), PSA is also finding out the learners' motivation in learning process.

\section{METHODS}

\subsection{Research Design}

This research used a case study method to find out the students' needs in terms of target needs, learning needs, and present situation of Office Authorization and Governance (OTKP). According to Yin (cited in Baxter \& Jack, 2008), case study is the method of answering questions "how" and "why." The case study also has meaning "analyzing" of the problems (Baxter \& Jack, 2008).

\subsection{Participant}

The research took place at one of vocational schools in Bandung, Indonesia. The researcher chose the research site as its accessibility in gaining the data of Office Authorization and Governance major. The participant of the research were 32 students of $10^{\text {th }}$ grade of one class and one English teacher in Office Authorization and Governance (OTKP) major. Three students were selected from 32 students as a result of the complete and interesting answers in the questionnaire. The three students were interviewed to clarify the answers, also got more information of students' needs.

\subsection{Data Collection and Analysis}

The data were collected by using three techniques: interview, questionnaire, and document analysis. The interview was done with one English teacher and three selected students. The respondents answered openended questions to provide interpretable data (Popping, 2015). The data from interview were used for analyzing students' learning needs and present situation (strengths and weaknesses in learning English). The questionnaire was collected from 32 students of $10^{\text {th }}$ grade of OTKP class at one vocational school in Bandung. According to Ponto (2015), questionnaires were delivered by using electronic format, in this case the researcher used Google Form. The data from questionnaire was used for analyzing students' target needs (necessities, lacks, and wants). As for document analysis, the data were collected from syllabus, lesson plans, textbook, and the assignments of the students. Document analysis is related to similar themes, and also the combination of qualitative and quantitative methods (Triad, 2016). Document analysis was collected to confirm the learning needs from the interview and target needs from the questionnaire.

\section{FINDINGS AND DISCUSSION 4.1. Findings \\ 4.1.1. Learning Needs}

The students need to achieve their goal in learning English, which is improving their English skills to fulfil the needs of the industries, especially in business, management and communication. Based on the interview, the OTKP students need to learn ESP for improving the speaking and writing skills, which follow by listening, reading, grammar and vocabulary (see Figure 1).

However, there are some problems in applying ESP in vocational school. First, the background of the students, which is affected by socio-economic and cultural background. In terms of socio-economic background, most of the students came from lower social economic status (SES) and need to work after graduating from vocational school. In line with this, the culture of the student also affects the students' thoughts 
of choosing vocational high school. Most of the students' family are also affecting their perception of importance of education, which have priority in work than education (Davis, 1951).

Second, the use of learning media, learning materials and technology also affect the students' learning needs. Those who have already appropriate equipment for learning activities in the classroom. However, there are some projectors and books that need some repair and improvement. The textbook used by the students is lack of ESP content, especially in vocabulary based on each major. In line with this, the teacher and the students said that they did not get what they need in the textbook, which most of the content are in general English (GE). The lack of teacher's knowledge and limited ESP content caused the students did not get the specific materials related to their major.

Third, the syllabus, lesson plans and students' assignments which still lack of specific materials. Syllabus is related to lesson plan, which plans and guides the teacher of the teaching and learning activity (Trigueros, 2015). In the syllabus, the materials are not specifically mentioned in GE or ESP. However, the teacher designed the lesson plans in GE, which are not appropriate to vocational students. As mentioned before, the lesson plans are not specifically designed in ESP, which is related to the students' assignments. The students' assignments are not certainly related to students' needs, which is English for Office Authorization and Governance.

The students were not fully aware of grammar and the choice of words, even though the type of the text was simple and easier to write than the other types of text. The student did not choose the specific topic to describe, such as kind of jobs in OTKP fields. However, he chose the general topic, which is a guitar. The student's text is shown in Figure 2.

Kita harus ningkatin speaking karena itu
adalah syarat untuk pekerjaan kita. Di
jurusan kita, siswa/inya bakal jadi
sekretaris, manajer, atau resepsionis sih
yang butuh kemampuan ngomong.
Speaking bakal membantu siswa/i
melakukan percakapan dengan orang
asing.
We should improve our speaking skill
due to the qualification of our job. In our
major, the students will be secretary,
manager, or receptionist which need
good speaking skill. The speaking skill
will help the students to have
conversation with foreigners. (Student 1)

Figure 1 Student's interview regarding to the needs of speaking skills

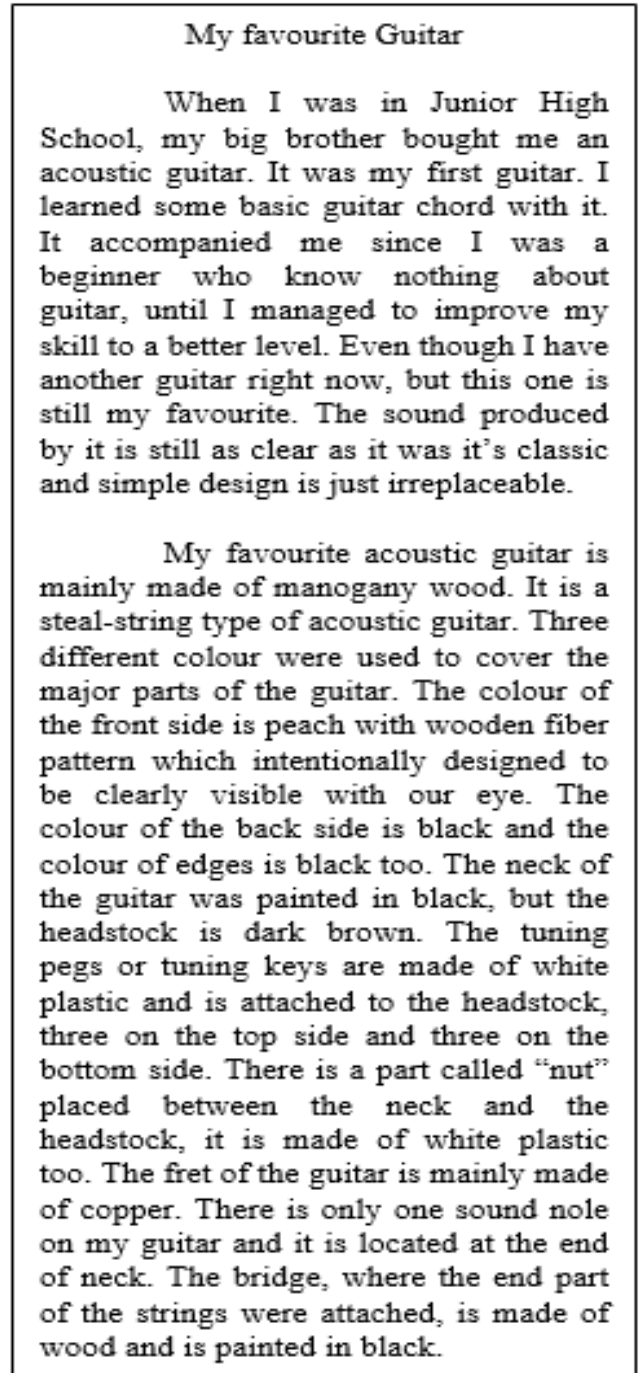

Figure 2 Student's Assignment Regarding to

Descriptive Text

This proves that the text written by the student is in General English (GE). In the text, there is no specific goal and relation between the guitar and OTKP field.

The OTKP students need ESP to improve their skills (listening, speaking, reading, writing, grammar and vocabulary). Most of the company related to Office Authorization and Governance need speaking and writing as the most needed skills to communicate in business context. Therefore, the students need ESP as their learning needs related to the work fields.

\subsubsection{Target Needs}

The findings of target needs were summarized from questionnaire of 32 students of $10^{\text {th }}$ grade in Office Authorization and Governance major at one of the vocational schools in Bandung. The questionnaire is divided into open-ended questions and close-ended questions. The open-ended questions asked the relation of learning needs and target needs. The close-ended questions asked the skills needed by the students in target situation, which are categorized into listening, speaking, reading, writing, grammar, and vocabulary. 
According to Hutchinston and Waters (1987), needs analysis is divided into three: learning needs, target needs and present situation analysis (PSA). The three needs analysis are related one to another. As mentioned before, the students' learning needs are related to the skills and knowledge in work fields, which is included in target needs. Target needs is the students' needs in terms of necessities, lacks and wants. The learning needs and target needs are related to students' skills, which need ESP for workplace. Based on the questionnaire, the target needs of students in Office Authorization and Governance (OTKP) are speaking skills to native speaker or non-native speaker regarding to the company, and writing documents of the company (formal letter, e-mail, or other forms of correspondence). They also need the listening and reading skills to support the speaking and writing skills. Learning needs and target needs are needed to achieve students' goals of English skills and knowledge, especially in specific purposes.

\subsubsection{Present Situation Analysis (PSA)}

According to Robinson (cited in $\mathrm{Li}, 2014$ ), present situation analysis is used to find out the strengths and weaknesses of students' competency in learning English. Based on the syllabus, lesson plans, students' assignments, learning media, technology and learning material (textbook), the students have not learned ESP in Office Authorization and Governance (OTKP) major. The problems happened in teaching and learning activity, it is lack of the teacher's knowledge in ESP, the unspecific lesson plans, and the GE textbook used in teaching and learning activity.

As mentioned before, the students learned GE in most of the materials given by the teacher. GE is also needed by the students to learn to know the basic skills of English. However, the vocational students also need ESP for improving specific skills to apply the skills in workplace. The strengths and weaknesses of learning GE in vocational school are listed on the Table 1.

Table 1. The strengths and weaknesses of learning GE in vocational school

\begin{tabular}{|c|c|}
\hline Strengths & Weaknesses \\
\hline $\begin{array}{l}\text { Teaching and learning } \\
\text { activity can achieve the } \\
\text { goals of learning English, } \\
\text { based on the syllabus. }\end{array}$ & $\begin{array}{l}\text { The teacher and the students } \\
\text { have low level of } \\
\text { understanding and willingness } \\
\text { to improve ESP skills. }\end{array}$ \\
\hline $\begin{array}{l}\text { The students are still } \\
\text { learning English for } \\
\text { mastering English skills } \\
\text { (listening, speaking, } \\
\text { reading, writing), in } \\
\text { general context. }\end{array}$ & $\begin{array}{l}\text { Lack of motivation and critical } \\
\text { thinking of learning ESP } \\
\text { makes the teacher and students } \\
\text { unprepared for using English } \\
\text { in workplace. }\end{array}$ \\
\hline $\begin{array}{l}\text { The students can } \\
\text { comprehend the } \\
\text { vocabulary in general } \\
\text { context. }\end{array}$ & $\begin{array}{l}\text { The GE in learning English } \\
\text { for vocational purposes is not } \\
\text { related to the students' needs, } \\
\text { which need ESP skills for } \\
\text { workplace. }\end{array}$ \\
\hline
\end{tabular}

\subsection{Discussions}

The students' learning needs are not achieved yet due to the general context used in teaching and learning activity. The students have not achieved the skills needed for learning English and working in company. The lack of teacher's knowledge in ESP is one of the factors in teaching and learning English. The teacher's quality should be improved by following teachers training related to designing ESP course (GorskaPorecka, 2013). In addition, the teacher needs specialization of knowledge regarding to students' target needs (Fouzia, 2015).

The skills needed are included in target needs, in terms of necessities, lacks and wants (Hutchinston \& Waters, 1987). Necessities is the demand of target situation, which mostly need speaking and writing skills. The OTKP students need to speak fluently to native and non-native speakers, while dealing in business matter. Furthermore, the writing skills needed by the students are writing e-mails, business reports and formal letters. The students need to be competent in four skills, as well as in grammar and vocabulary, which need to be improved to meet the demand of target situation (necessities). In order to meet target needs, the students are also having "wants," which regularly in contrast with necessities and lacks (Hutchinston \& Waters, 1987); (Paltridge \& Starfield, 2013). Most of the students want to learn English in fun way, such as playing games as main activity. The students' wants cannot be fulfilled as main activity regarding to the necessities and lacks which should be achieved for comprehending students' skills.

Furthermore, present situation analysis (PSA) is needed to find out the strengths and weaknesses of students' learning activity. The students who have weaknesses in learning English can develop the motivation and self-confidence (Listyani \& Tananuraksakul, 2019). The students have to practice more skills, especially speaking and writing which are needed in target needs. The strengths of learning English for vocational school need to be properly done, still needs improvement in giving specific learning activity and materials.

\section{CONCLUSION}

The student's learning needs had to be improved to meet the skills in target situation. The students' learning needs are affected by the socio-economic background, which the students have priorities on work. Some students also want to continue their study to university by taking employee courses. Currently, the learning media, technology and learning materials were not well functioned and properly match to students' learning needs. The textbook used is in GE, which is not appropriate with students' needs. In line with this, the lesson plans and students' assignments are also designed in the context of GE. In addition, the teacher did not 
teach ESP due to the lack of knowledge in ESP and EVP for OTKP. Therefore, in general, the students who need specific materials regarding to the OTKP major cannot achieve their target needs.

Target need analysis described what skills needed regarding to OTKP major. The most needed skills are speaking and writing, which are usually needed in business context. OTKP is one of fields that deals with secretary, manager, receptionist, and so on. The speaking skills is needed in order to communicate to native and non-native speakers for gaining information. The writing skills is needed for writing the report of the company, writing letter or e-mail. Furthermore, the listening skills, reading skills, grammar and vocabulary are also needed by the students to support speaking and writing skills.

The present situation analysis showed the students' learning needs. The present situation has strengths and weaknesses in learning GE for vocational school. In terms of strength, it can still improve the skills and meet the students' learning needs, although in general context. In contrast, the weaknesses are that the students cannot improve their specific skills related to OTKP, and the lack of teacher's knowledge in ESP causes the students cannot meet their learning and target needs in specific context.

The OTKP students need more specific materials rather than general materials. The specific materials learned in the class will help the students to achieve the target needs, which is the qualification to get the job and work in the company. In addition, the students need the improvement in English skills, especially speaking and writing related to OTKP context.

\section{REFERENCES}

Akyel, A., \& Ozek, Y. (2010). A language needs analysis research at an English medium university in Turkey. Procedia Social and Behavioral Sciences 2, 969-975.

Aniroh, K. (2017). Research and trends of ESP in Indonesia. The Asian EFL Journal Professional Teaching Articles, 8(97), 85-105.

Baxter, P., \& Jack, S. (2008). Qualitative Case Study Methodology: Study design and implementation of novice researchers. The Qualitative Report, 544559.

Davis, A. (1951). Socio-economic influences on learning. Phi Delta Kappa International, 253-256.

Feak, C. B. (2013). ESP and speaking. In B. Paltridge, \& S. Starfield (Eds.), The Handbook of English for Specific Purposes (pp. 35-53). Chichester, UK: John Wiley \& Sons, Inc.

Fouzia, B. (2015, February Thu). What are qualities of ESP teachers? What are their beliefs about teaching and learning? Retrieved from Research Gate:

https://www.researchgate.net/post/What_are_qualit
ies_of_ESP_teachers_What_are_their_beliefs_abo ut_teaching_and_learning

Gorska-Porecka, B. (2013). The role of teacher knowledge in ESP course design. Studies in Logic, Grammar and Rhetoric, 27-42.

Hutchinston, T., \& Waters, A. (1987). English for Specific Purposes: A learning-centred approach. New York: Cambridge University Press.

Indonesia, G. B. G. (2016). Global Business Guide Indonesia. Retrieved from gbgindonesia: http://www.gbgindonesia.com/en/education/article/ 2016/vocational_education_in_indonesia_crucial_ to_compete_in_the_asean_11489.php

Kareva, V. (2013). Improving quality in English language teacher education. Procedia - Social and Behavioral Sciences, 1482-1486.

2014). Teaching English for Academic Purposes. Canada: TESOL Press.

Lesiak-Bielawska, E. D. (2012). The impact of blended learning on teaching English for vocational purposes. Adam Mickiewicz University Press, 4756.

Li, J. (2014). Needs Analysis: An effective way in business English curriculum design. Theory and Practice in Language Studies, 1869-1874.

Listyani, \& Tananuraksakul, N. (2019). Motivation, Self-Confidence, and Anxiety in English Language Learning: Indonesian and Thai students' perspectives. Accents Asia, 54-77.

Long, M. H. (2005). Second Language Needs Analysis. New York: Cambridge University Press.

Mahbub, M. A. (2018). English Teaching in Vocational High School: A need analysis. Journal of English Education and Linguistics Studies, 230.

Marra, M. (2013). English in the Workplace. In B. Paltridge, \& S. Starfield, The Handbook of English for Specific Purposes (pp. 175-188). Chichester, UK: John Wiley \& Sons, Inc.

Paltridge, B., \& Starfield, S. (2013). ESP and language skills. In B. Paltridge, \& S. Starfield (Eds.), The handbook of English for specific purposes (pp. 3134). Chichester, UK: John Wiley \& Sons, Inc.

Poedjiastutie, D., \& Oliver, R. (2017). English Learning Needs of ESP Learners: Exploring stakeholder perceptions at an Indonesian university. TEFLIN Journal, 1-21.

Ponto, J. (2015). Understanding and evaluating survey research. Journal of the Advanced Practitioner in Oncology, 168-171.

Popping, R. (2015). Analysing open-ended questions by means of text analysis procedures. Bulletin de Methodologie Sociologique, 23-39.

Rao, V. C. (2017). English for business and management. Journal for Research Scholars and Professionals of English Language Teaching. 
Sarmento, S., Viana, V., \& Bocorny, A. E. (2018). English for Specific Purposes (ESP). Brazil: TESOL Press.

Triad. (2016, March Wed). An Introduction to Document Analysis. Retrieved from Research Methodology in Education: https://lled500.trubox.ca/2016/244

Trigueros, R. (2015). Lesson Plan. El Salvador: University of El Salvador.
Widodo, H. P. (2016). Teaching English for Specific Purposes (ESP): English for vocational purposes (EVP). English Language Education, 277-290.

Zhang, Y. (2016). Research on the office administration management new ideas and countermeasures under fine management perspective. International Symposium Technology, Education and Management (ISETEM). 